\title{
$\left[\begin{array}{ll}{[} & 561\end{array}\right]$
}

\section{XXXV.- Notice of the Discovery of a mass of Trap Rock in the Mountain Limestone of Bleadon Hill, in the County of Somerset.}

By the Rev. D. WILLIAMS, F.G.S.

[Read June 10th, 1840.]

I FEEL much pleasure in announcing to the Society, that a cutting for the Bristol and Exeter railway through the extreme western termination of Bleadon Hill has within these few days disclosed a mass of fine porphyritic trap, the first instance hitherto observed of the occurrence of an igneous rock in the Mendip Hills, or within the area of the Bristol coal-field. The trap varies from a granular greenstone with hornblende to a compact porphyritic rock, inclosing amygdaloidal kernels of calcareous spar and brown hematite; other specimens exhibit crystals of glassy felspar, and the rock is sometimes laminated and friable. The bed of mountain limestone which rests immediately on the trap differs in colour, and is much more brittle than the other strata.

Rare as such igneous products are in this region, they are scarcely less so throughout the whole of Exmoor and the Quantocks; for, except the syenitic granite and trappean porphyry of Hestercomb in the Quantocks, first noticed by Mr. Horner*, a slaty porphyry I met with a little north of Simmons-birth in Exmoor, and the elvan blocks near Morte Point, mentioned by Mr. De la Beche†, all associated with the same slate series (No. 5. of my subdivision), which rests on the granite of Lundy Island, I know of none. The next nearest igneous rocks are those about Tortworth in Gloucestershire, in the Caradoc sandstone division of the Silurian system of Mr. Murchison.

The cutting for the railway intersects the broadest part of the ridge of lias and new red sandstone, which I formerly pointed out $\ddagger$ as filling up a great interval or original gorge between the limestone of Bleadon and Uphill.

* Geol. Trans., First Series, vol. iii. p. 348, 1816.

+ Report, Geology of Cornwall and Devon, pp. 49, 186, 1839 .

$\ddagger$ Geol. Proceedings, vol. ii. p. 79, 1833. 
562 Rev. D. Williams on Trap Rock in the Mountain Limestone of Bleadon Hill.

For the principal details represented in the accompanying woodcut $I$ am indebted to Mr. Peniston the resident engineer, who had the kindness to prepare for me a graphic representation of the whole cutting, but of which only a portion is here given.

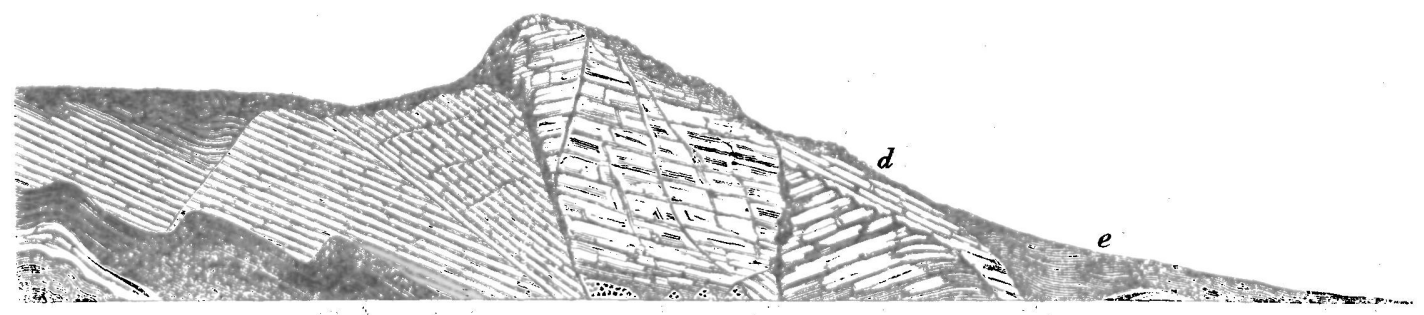

